\title{
PENGARUH FINANCIAL LITERACY, LOCUS OF CONTROL, LIFESTYLE, DAN GENDER TERHADAP FINANCIAL MANAGEMENT BEHAVIOR MAHASISWA UNIVERSITAS NEGERI SURABAYA
}

\author{
Novita Sari \\ Universitas Negeri Surabaya \\ novita.17080574091@mhs.unesa.ac.id
}

\begin{abstract}
Financial management behavior is essential to have for everyone to achieve their financial goals. This research aimed to determine financial literacy, locus of control, lifestyle, and gender on financial management behavior. Respondent to this research is the students of Universitas Negeri Surabaya. The sample number is 100 respondents with random sampling obtained from online questionnaires - the research method uses a quantitative approach. Data were analyzed using multiple linear regression and processed using SPSS 23. The result of this research is that the variables of financial literacy, locus of control, lifestyle, and gender positively affect personal financial planning. Universitas Negeri Surabaya, especially the student career development section and the Financial Services Authority (OJK), can use this study's results to educate millennials about the importance of managing and planning finances properly.
\end{abstract}

Keywords: financial literacy; financial management behavior; gender; lifestyle; locus of control

\section{PENDAHULUAN}

Kepiawaian literasi finansial penting untuk dijadikan fokus, tidak terkecuali untuk anak muda. Kepiawaian mengelola finansial dengan baik juga menjadi fokus utama selain pemahaman finansial. Pentingnya pengelolaan finansial tidak hanya untuk pertahanan hidup, melainkan memersiapkan diri menghadapi krisis ekonomi yang mungkin saja akan muncul.

Jumlah penduduk Indonesia 24 persenya merupakan kalangan anak muda dengan taraf literasi sekitar 32,1 persen berdasarkan riset OJK. (Siregar, 2020). Namun, masih banyak anak muda yang lemah secara keuangan, ini dikarenakan masih sedikitnya persiapan dan kemampuan pengelolaaan keuangan. Dari segi jumlah populasi, karakter, serta akses terhadap teknologi anak muda berpotensi besar sebagai penggerak roda ekonomi (Ningtyas, 2019).

Data Kementerian Riset, Teknologi dan Pendidikan tinggi 2020 menunjukkan jumlah mahasiswa di Kota Surabaya sangatlah tinggi dibandingkan kota lain seperti Kota Malang dan Kota Madiun. Surabaya memiliki 6 perguruan tinggi negeri dan 72 perguruan tinggi swasta. Univesitas Negeri Surabaya adalah salah satu diantaranya yang memiliki jumlah mahasiswa terbanyak. Didasarkan Pangkalan Data Perguruan Tinggi 2020 jumlah mahasiswa baru Universitas Negeri Surabaya jenjang S1 sebanyak 5.677 mahasiswa (PDDIKTI, 2020). Dengan jumlah mahasiswa yang sedemikian banyak seharusnya mampu melahirkan kaum anak muda yang memiliki tingkat keterampilan dan kemampuan pengelolaan keuangan yang tinggi (Indepth.com, 2020). Kemampuan dan wawasan dalam mengelola keuangan merupakan faktor utama untuk bekal di masa depan guna menghadapi ketidakpastian. Pengelolaan keuangan haruslah didukung dengan adanya keterampilan dalam menyelesaikan masalah finansial. Keterampilan dan kemapuan dalam mengelola keuangan sangatlah penting untuk semua kalangan, baik yang tua maupun yang muda, terutama di kalangan mahasiswa (Suryanto, 2017).

Hasil penelitian Suryanto (2017) terhadap mahasiswa FISIP Universitas Padjajaran terbukti bahwa rata-rata mahasiswa tidak membuat catatan pengeluaran, sehingga sering terjadi defisit keuangan. Mahasiswa cenderung membelanjakan dana yang dimilikinya tanpa pertimbangan yang matang, mereka akan membelanjakan apapun yang mereka suka tanpa memertimbangkan nilai guna, yang terpenting bagi mereka adalah mengikuti tren yang sedang marak. Sebagian besar mahasiswa belum memiliki pendapatan yang berasal dari pendapatan yang mereka hasilkan sendiri, melainkan mereka 
mendapatkan uang dari orang tua yang biasanya mereka peroleh setiap bulan. Perencanaan pengelolaan keuangan haruslah dilakukan oleh mahasiswa agar pengeluaran mereka tidak melebihi batas uang yang diberikan oleh keluarga mereka.

Data pengeluaran 2017 di sektor bukan makanan lebih besar dibanding pengeluaran di bidang makanan. Pada tahun 2017 Kota Surabaya memiliki pengeluaran untuk kegiatan bukan makanan mencapai 60\% dan 59\% pada 2016 (BPS, 2018). Kehidupan bergaul sehari-hari, lingkungan pertemanan sangat berperan penting dalam memerlihatkan keberadaan anak muda dalam pergaulannya. Kegiatan menyimpan uang cenderung tidak dengan tujuan persiapan membeli barang yang mungkin dibutuhkan di masa depan, melainkan untuk menunjang kebutuhan bergaul seperti, kumpul bersama teman, belanja (Halimatussakdiyah et al., 2019).

Sikap tidak mau tahu pada konsep keuangan dapat berdampak buruk. Contohnya, apabila tidak mampu memahami konsep terkait bunga, kedepannya akan mengakibatkan semakin besar utang yang harus ditanggung, bahkan bisa terperangkap dengan pinjaman online serta rentenir. Saat ini banyak pengusaha muda yang berasal dari kalangan mahasiswa yang penghasilannya cukup besar, akan tetapi sebagian besar dari mereka masih awam akan perencanaan keuangan (Azizah, 2020)

Literasi keuangan berperan penting pada perilaku keuangan individu itu sendiri. Financial literacy bisa dimaknai sebagai wawasan keuangan yang bertujuan mendapatkan harta. Perilaku finansial yang baik,kepemilikan tabungan, serta pengelolaan pinjaman bank dipengaruhi oleh tingkat literasi yang tinggi (Herawati et al., 2018). Survei Nasional Literasi dan Inklusi Keuangan (SNLIK) tahun 2016 literasi keuangan sebesar 29,66 \%, kemudian 2019 indeks literasi keuangan sebesar 38,03\% dan indeks inklusi keuangan 76,19\% (Otoritas Jasa Keuangan, 2019). Indeks tersebut mengalami peningkatana dibanding indeks 2016. Akan tetapi indeks tersebut tetap harus ditingkatkan sebab indeks harapan yang dicanangkan oleh pemerintah dalam Peraturan Presiden Republik Indonesia Nomor 82 Tahun 2016 tentang Strategi Nasional Keuangan Inklusif (SNKI) adalah 75\% pada tahun 2019.

Pembelajaran membaca di Indonesia cenderung kurang mengikuti perkembangan zaman dan umumnya pembelajaran diberikan tidak seutuhnya. Pembelajaran matematika pada tingkat sekolah dasar contohnya. Akibatnya, tingkat kompetensi membaca masyarakat Indonesia juga berada diperingkat terakhir, yaitu 72 dari 78 partisipan survei Programme for International Student Assessment (PISA) di bidang menghitung (Kencana, 2020).

Tingkat pemahaman finansial individu tinggi, sejalan dengan peningkatan kemampuan mengatur serta mengalokasikan keuangan dengan tepat, sehingga memberikan pengaruh positif terhadap perilaku pengelolaan keuangan individu tersebut (Robb \& Woodyard, 2011). Menurut Widyawati (2012) tindakan seseorang berkaitan dengan seberapa banyak dana yang harus dikeluarkan setiap bulannya, adakah sisa, kemudian sisa yang ada akan diinvestasikan seperti apa. Literasi keuangan memiliki peran penting untuk perencanaan keuangan, khususnya di kalangan milenial.

Pengendalian diri individu yang baik maka akan berdampak pada sikap keuangan individu semakin baik. Locus of control dibutuhkan oleh individu untuk mengelola keuangannya. Studi tentang pengendalian diri yang memprediksi sikap keuangan dan kesejahteraan keuangan menunjukkan bahwa pengendalian diri memengaruhi secara positif kepada perilaku finansial secara umum. seseorang dengan pengendalian diri yang bagus memiliki sedikit permasalahan berkaitan dengan keuangan dan lebih aman serta percaya diri dalam situasi keuangan mereka saat ini dan di masa depan (Purwidianti, 2018).

Perkembangan ilmu dan teknologi seharusnya mendukung semakin pesatnya pengetahuan di bidang keuangan. Melihat dari hasil riset terdahulu baik dari pemerintah maupun peneliti lain masih menunjukkan bahwa tingkat kemampuan pengelolaan keuangan anak muda masih rendah (Margaretha \& Pambudhi, 2015). 
Novita Sari. Pengaruh Financial Literacy, Locus of Control, Life Style, dan Gender terhadap Financial Management Behavior Mahasiswa Universitas Negeri Surabaya

Variabel pertama yang diteliti adalah financial literacy-merupakan salah satu cara untuk meningkatkan pemberdayaan kualitas hidup. Mahasiswa yang mendapat wawasan terkait prinsip dasar keuangan yang lebih luas, dapat dengan bijak menghasilkan keputusan. Hal ini terlihat dari keterampilan mahasiswa dalam mengelola keuangan pribadi dan mengelola investasi yang baik (Azizah, 2020). Financial literacy menunjukkan pengaruh positif dan signifikan terhadap pengelolaan finansial (Herawati et al., 2018). Namun Nidar dan Bestari (2012) menyampaikan pemahaman finasial memengaruhi secara positif perilaku pengelolaan finansial, akan tetapi kemampuan pemahaman finasial mahasiswa masih berada pada kategori rendah.

Locus of control adalah variabel kedua yang diteliti. Seseorang memandang apa yang terjadi dalam hidupnya bergantung pada perilaku yang dilakukan (Rizkiawati \& Asandimitra, 2018). Individu tersebut merasa selalu bisa menyelesaikan masalah dan lebih percaya pada kondisi keuangannya saat ini, hal tersebut disebabkan oleh keterampilan dan usaha yang sudah dilakukannya. Locus of control memberikan pengaruh signifikan positif terhadap financial managent behavior (Rizkiawati \& Asandimitra, 2018). Tetapi locus of control dari luar berpengaruh negatif pada financial manangement behavior (Mien dan Thao, 2015).

Variabel ketiga adalah lifestyle yang dapat dilihat dari serangkaian kegiatan, keinginan, serta pendapat seseorang. Untuk memenuhi gaya hidup yang diinginkan, seseorang akan lebih bersikap konsumtif tanpa adanya pertimbangan matang, hal tersebut dapat mengakibatkan terjadinya tindakan pengeluaran uang yang tidak terkontrol apabila tanpa diimbangi dengan pengelolaan keuangan. Life style berpengaruh signifikan positif terhadap financial behavior seseorang (Dewi dan Haryana, 2020).

Variabel terakhir yang diprediksi memengaruhi tingkat financial literacy mahasiswa adalah gender. Perempuan mempunyai taraf financial literacy lebih baik dibanding laki-laki (Margaretha dan Pambudhi, 2015). Menurut Rizkiawati dan Asandimitra (2018) jenis kelamin tidak memengaruhi financial management behavior, di mana semua gender memiliki peluang yang seimbang dalam pengelolaan finansial. Berdasarkan latar belakang di atas, tujuan penelitian ini menganalisis pentingnya pemahaman tentang financial literacy, locus of control, life style, dan gender dalam pengelolaan keuangan pada responden mahasiswa Unesa.

\section{KAJIAN PUSTAKA DAN PENGEMBANGAN HIPOTESIS}

\section{Theory of Planned Behavior (TPB)}

Menurut Ajzen (1991) teori ini mendasari seseorang berperilaku sesuai keinginan sendiri tanpa paksaan, yang berpedoman pada perhitungan yang logis mengenai dampak dari perilaku yang lakukan, dan seperti apa reaksi ataupun pandangan orang lain terhadap hal tersebut. TPB menyajikan acuan mengenai tindakan terhadap perilaku. Tindakan tersebut antar lain: keyakinan akan sebuah tindakan , penilaian pada suatu tindakan,pandangan mengenai tekanan sosial terkait suatu perilaku, keyakinan pada kaidah yang berlaku, serta dorongan selalu taat.

TPB didasari atas dugaan manusia merupakan makhluk dengan pemikiran logis serta menyerap semua berita secara teratur sesuai dengan sistem yang ada. Dalam teori ini, seseorang diasumsikan memiliki pengetahuan atau informasi, keyakinan serta keterampilan mengenai analisis peluang dan konsekuensi terhadap perilaku keuangan yang dilakukan(Ajzen, 2005). Variabel financial literacy dan gender dalam penelitian ini dijelaskan menggunakan TPB.

\section{Social Learning Theory}

Teori pembelajaran sosial dilandasi lima anggapan terkait tindakan seseorang antara lain seseorang bersinggungan dengan lingkungan yang dianggapnya penting, kepribadian seseorang sifatnya terus dipelajari, kepribadian seseorang memiliki satu kesatuan mendasar, seseorang melakukan sesuatu berdasarkan apa yang ingin dicapai, dan seseorang mampu menangani masalah yang muncul (Rotter, 1966). Perilaku seseorang dapat diprediksi melalui: pertama behavior yang besar kemungkinan muncul, pengharapan, nilai penguatan, dan keadaan psikologi. Social learning theory dalam penelitian 
ini digunakan menjelaskan variabel locus of control yang dapat memengaruhi financial management behavior(Rizkiawati \& Asandimitra, 2018).

\section{Value and Life Style (VALS)}

VALS merupakan klasifikasi paling popular yang didasarkan pada ukuran-ukuran psikografis. VALS merupakan klasifikasi terkemuka yang didasarkan pada tingkat kepuasan seseorang terkait gaya hidup. Standar Research Institute (SRI) mengemukakan terkait ilmu yang mempelajari pengelompokan jenis VALS untuk pembagian pasar dan menentukan sasaran usaha-usaha promosi. Values adalah berbagai nilai yang dianut oleh individu. Nilai ini menjadi prinsip yang mengarahkan kehidupan seseorang dan suatu nilai yang dimiliki menunjukkan sesuatu yang yang berharga dalam kehidupan ini penting atau tidak. VALS membagi individu menjadi delapan kelompok yaitu: survivor, sustainers, belongers, emulators, achievers, $i$-am-me, experientals, dan sosially conscious. (Kunto \& Pasla, 2006).

Teori hirarki kebutuhan manusia Abraham H. Maslow menjelaskan tingkatan kebutuhan manusia, yaitu kebutuhan fisiologi, kebutuhan akan keamanan, kebutuhan kasih sayang, dan aktualisasi diri. Dari setiap kebutuhan tersebut VALS menelaah value yang digunakan manusia. (Kunto \& Pasla, 2006). Teori dorongan kepribadian oleh Riesman, Glazer dan Denney (1950). Istilah other directed berubah outer directed atau dorongan dalam VALS. Dua teori tersebut merupakan gabungan teori yang digunakan pendekatan VALS. VALS dalam penelitian ini akan menjelaskan bagaimana seseorang mendapat dorongan dan menentukan gaya hidupnya yang kemudian akan memengaruhi perilaku pengelolaan finansial individu tersebut. (the inner and outer directed personality theory) (Kunto \& Pasla, 2006)

\section{Financial Management Behavior}

Perilaku pengelolaan finansial merupakan konsep berkaitan dengan keteraturan finansial,bentuk perilaku pengelolaan finansial seperti akuisisi, alokasi dan pemanfaatan sumberdaya finansial Menurut penelitian Dew dan Xiao, (2011) financial management behavior seseorang dapat dilihat dari empat hal yaitu, konsumsi, arus kas, tabungan, manajemen kredit. Financial management behavior diukur menggunakan skala likert. Tingkat pemahaman manajemen perilaku seseorang dapat diukur menggunakan indikator: pemahaman seseorang terhadap pentingnya menabung, kemampuan menentukan anggaran, dan kesadaran seseorang akan pentingnya berhemat (Azizah, 2020).

\section{Financial Literacy}

Financial literasi ialah serangkaian kegiatan guna menaikkan tingkat wawasan, kepercayaan, serta kepiawaian pelanggan atau khlayak umum akibatnya akan timbul kemampuan pengelolaan finansial yang lebih bijak (Otoritas Jasa Keuangan, 2019). Sedangkan menurut Dikria dan Mintarti (2016), financial literacy merupakan tingkat wawasan dasar tentang pengelolaan keuangan, dari pemasukan hingga pengeluaran. Dewi dan Haryana (2020) menyatakan financial literacy ialah kepiawaian menyusun berita dan menentukan keputusan secara tetap terhadap pemakaian dan manajemen finansial individu. Indikator untuk literasi keuangan berkaitan dengan pengetahuan tentang keuangan secara umum, pemahaman pentingnya menabung dan investasi (Azizah, 2020). Variabel financial literacy diukur menggunakan skala likert

\section{Locus of Control}

Pengendalian diri dibutuhkan individu untuk mengelola keuangannya. Jika pengendalian diri individu baik maka perilaku keuangan individu juga semakin baik. Studi tentang pengendalian diri yang memprediksi financial behavior dan kesejahteraan financial menunjukkan bahwa kontrol diri memiliki pengaruh positif terhadap financial behavior secara umum (Purwidianti, 2018). Pengendalian diri individu yang baik memiliki sedikit masalah berkaitan dengan finansial serta lebih yakin kepada diri sendiri dalam situasi finansial mereka di masa kini dan di masa depan (Purwidianti, 2018). Individu dengan locus of control dari dalam berkecenderung pada tindakan, dorongan, serta lebih memilih melaksanakan pekerjaan rumit daripada individu dengan locus of control dari luar Menurut (Ida \& Dwinta, 2010). Hal ini dikarenakan orang dengan locus of control eksternal kecil 
Novita Sari. Pengaruh Financial Literacy, Locus of Control, Life Style, dan Gender terhadap Financial Management Behavior Mahasiswa Universitas Negeri Surabaya

potensi dapat mengeluarkan usaha yang dibutuhkann guna memperlihatkan sikap pengelolaan keuangan dengan penuh tanggung jawab. Merujuk pada Sriwijaya (2017) indikator variabel ini yaitu terdiri dari kemampuan memecahkan masalah pribadi, percaya akan kemampuan diri sendiri, dan kontrol diri. Skala likert yang digunakan untuk mengukur indikator-indikator ini.

\section{Life Style}

Life style secara umum diartikan sebagai cara hidup yang ditelaah oleh cara individu menggunakan waktunya (kegiatan), sesuatu yang dianggap penting dalam lingkungannya (minat), dan pemikiran seperti apa mengenai diri dan kehidupan mereka (opini) (Setiadi, 2003). Life style seseorang dengan lainnya pastinya memiliki perbedaan. Bahkan dari waktu ke waktu life style orang yang satu dengan yang lain akan terus bergerak dinamis. Akan tetapi life style tidak mengalami perubahan yang cepat, sehingga dalam kurun waktu tertentu life style relatif bertahan. Skala likert yang digunakan untuk mengukur indikator aktivitas, minat, dan opini

\section{Gender}

Variabel gender dijelaskan oleh theory of planned behavior, bahwa gender seseorang akan berpengaruh terhadap cara pikir dan keputusan dalam perencanaan keuangan, karena laki-laki dan wanita mempunyai perbedaan beban yang ditanggung (Yunita, 2020). Selaras dengan asumsi mengenai individu bertindak atas dasar keinginannya sendiri, berdasarkan pada perkiraan logis mengenai dampak paling mungkin muncul dari sikap yang mereka lakukan. Gender ialah bagian dari konsep diri terkait dengan telaah seseorang sebagai wanita ataupun pria (Baron \& Byrne, 2000). Gender merupakan variabel dummy yang diukur dengan angka, yakni karena pria memiliki tanggung jawab lebih besar di dalam keluarga dan harus lebih memahami pengelolaan keuangan yang lebih baik maka pria dengan angka 1 dan wanita angka 0 (Kostakis, 2012).

\section{Hubungan Antar Variabel}

Financial literacy merupakan wawasan finansial dan kepiawaian dalam pengelolaan finansial pribadi. Financial literacy ialah kebutuhan mendasar setiap individu supaya terhindar dari permasalahan finansial (Yushita, 2017). Variabel financial literacy dijelaskan dengan theory planned of behavior. Financial literacy sangatlah berdampak terhadap financial behavior anak muda, ini akan mengindikasi bahwa semakin baik wawasan kalangan anak muda dalam pengelolaan finansial maka akan semakin baik pula dalam memertanggungjawabkan pengambilan keputusan terhadap keuangan pribadi (Azizah, 2020).

\section{H1: Financial literacy berpengaruh terhadap financial magement behavior.}

Hubungan antara locus of control dan financial management behavior ditunjukkan arah signifikansi positif, karena locus of control merupakan variabel kepribadian bersifat kecenderungan, setiap orang mempunyai kedua hal itu yakni kecenderung dengan locus of control internal atau kecenderungan locus of control eksternal akan memengaruhi perilaku keuangan orang tersebut (Kholilah \& Iramani, 2013).

\section{$\mathrm{H} 2$ : Locus of control berpengaruh terhadap financial management behavior.}

Perkembangkan life style orang-orang yang tinggal di perkotaan dapat diidentifikasi melalui, berubahnya life style masyarakat, munculnya berbagi jenis gaya bangunan yang semakin beragam mengikuti perkembangan waktu (Putri \& Lestari, 2019). Metropolitan life style muncul didukung oleh mereka-mereka yang termasuk ke dalam kelas menengah ke atas. Sebagian besar dari mereka yang merupakan seorang profesional sudah bekerja keras, dan memiliki pendapatan yang lebih, sehingga mereka ingin menikmati hidup yang lebih baik lagi (Dewi \& Haryana, 2020).

\section{H3: Life style berpengaruh terhadap financial management behavior.}

Yunita (2020) menyatakan bahwa gender berpengaruh signifikan terhadap perilaku keuangan seseorang. Berdasarkan observasi yang telah dilakukan, laki-laki melakukan perencanaan keuangan 
lebih baik daripada wanita karena laki-laki memiliki pola pikir yang lebih logis dan rasa tanggung jawab untuk memenuhi kebutuhan biaya hidup keluarganya. Akan tetapi perempuan memiliki taraf pemahaman keuangan lebih tinggi dibanding laki-laki (Margaretha \& Pambudhi, 2015)

H4: Gender berpengaruh terhadap financial management behavior.

\section{METODE PENELITIAN}

Penelitian ini menggunakan paradigma kuantitatif. Data yang digunakan adalah data primer. diperoleh dari penyebaran kuesioner melalui google form. Variabel bebas penelitian ini adalah financial literacy, locus of control, life style, dan gender, serta variabel terikat adalah financial managemen behavior. Mahasiwa aktif Universitas Negeri Surabaya angkatan 2017 hingga 2020 adalah populasi penelitian ini. Jumlah 100 responden, diambil dengan menggunakan teknik random sampling, angka 100 responden hasil dari penghitungan menggunakan rumus Slovin. Penyebaran kuesioner dilakukan online melalui .media sosial seperti whatsapp, telegram, maupun media sosial yang lain. Data diuji menggunakan regresi linier berganda, dengan SPSS 23.

\section{HASIL DAN PEMBAHASAN}

\section{Uji Validitas}

Variabel financial literacy, locus of control, life style, dan financial management behavior diuji menggunakan aplikasi SPSS 23. Menurut Sujarweni (2015:108), data dikatakan valid jika hasil $\mathrm{r}$ hitung $>\mathrm{r}$ tabel. Hasil $\mathrm{r}$ tabel 35 responden adalah 0,3338. Sedangkan hasil $\mathrm{r}$ tabel 100 responden sebesar 0,1966. Dari hasil tersebut, item dari pertanyaan dinyatakan valid.

\section{Uji Reliabelitas}

Menurut Sujarweni (2015:110) dinyatakan reliabel apabila memiliki nilai cronbach's alpha sebesar > 0,60. Hasil pengujian, variabel financial literacy dengan cronbach's alpha sebesar 0,698; variabel locus of control dengan cronbach's alpha sebesar 0,837; variabel life style dengan cronbach's alpha sebesar 0,743, dan cronbach's alpha sebesar 0,776 variabel financial management behavior. Data dari penelitian ini reliabel dan dapat dilanjutkan ke uji selanjutnya.

\section{Uji Normalitas}

Uji normalitas untuk mengetahui data berdistribusi normal atau tidak. Apabila berdistribusi normal maka data layak digunakan untuk uji selanjutnya. Menurut Sujarweni (2015:225) menggunakan uji K$S$ data dengan nilai signifikan $>0,005$ berdistribusi normal. Pada penelitian ini data memiliki nilai signifikansi pada uji K-S sebesar 0,200 sehingga data berdistribusi normal.

\section{Uji Multikolenieritas}

Menurut Sujarweni (2015:228) dikatakan tidak mengalami gejala multikolinieritas jika nilai VIF $\leq 10$ dan nilai tolerance $\geq 0,10$. Nilai tolerance dengan perincian berikut: variabel financial literacy 0,663 ; variabel locus of control 0,722 ; variabel life style 0,924 ; variabel gender 0,866 , dan nilai VIF dengan perincian berikut: variabel financial literacy 1,0508; variabel locus of control 1,384; variabel life style 1,082; variabel gender 1,155 pada semua variabel bebas dalam penelitian ini sebesar $\leq 0,10$ dan $\geq 10$. Berdasarkan nilai tersebut maka model regresi bebas multikolinieritas.

\section{Uji Heterokedastitas}

Uji heterokedastisitas dengan uji glejser SPSS. Hasil pengujian menghasilkan nilai signifikansi berikut; variabel financia literacy sebesar 0,398; locus of control sebesar 0,973; life style sebesar 0,950 . nilai signifikansi yang dihasilkan > 0,005 maka sesuai dengan dasar pengujian dalam uji glejser, model regresi tidak ada heteroskedastisitas.

\section{Regresi Linier Berganda}

Tabel 1 hasil uji regresi linier berganda ditunjukkan dengan persamaan regresi (1). 
Novita Sari. Pengaruh Financial Literacy, Locus of Control, Life Style, dan Gender terhadap Financial Management Behavior Mahasiswa Universitas Negeri Surabaya

$\mathrm{Y}=-0,335+0,2297 \mathrm{FL}+0,449 \mathrm{LC}+0,109 \mathrm{LS}+\mathrm{e}$.

Tabel 1

HASIL UJI REGRESI LINIER BERGANDA

\begin{tabular}{|c|c|c|c|c|}
\hline \multirow{2}{*}{ Model } & \multicolumn{2}{|c|}{ Unstandardized Coefficients } & \multirow{2}{*}{$\mathbf{T}$} & \multirow{2}{*}{ Sig. } \\
\hline & & Std. Error & & \\
\hline (Constant) & $-0,335$ & 2,863 &,- 117 & .907 \\
\hline Financial literasi $(F L)$ & 297 & , 100 & 2,961 & ,004 \\
\hline Locus of control ( $L C)$ & ,499 & ,103 & 4,845 & ,000 \\
\hline Life style (LS) & , 109 & ,045 & 2,420 & ,017 \\
\hline Gender & 1,302 &, 552 & 2,359 &, 020 \\
\hline
\end{tabular}

Sumber: Output SPSS (data diolah)

\section{Uji Statistik F}

Nilai probabilitas $\mathrm{F}$ hitung sebesar 0,000 lebih kecil dari tingkat signifikansi dan nilai $\mathrm{F}$ hitung sebesar 19,946, sehingga model layak digunakan serta semua variabel bebas secara bersamaan memengaruhi financial management behavior.

\section{Uji Statistik t}

Nilai probabilitas t hitung variabel bebas dengan rincian berikut: variabel financial literacy sebesar 2,961 dengan nilai signifikansi $0,004<0,05$; variabel locus of control sebesar 4,845 dengan nilai signifikansi 0,000 < 0,05; variabel life style sebesar 2,420 dengan nilai signifikansi $0,017<0,05$, dan variabel gender sebesar 2,359 dengan nilai signifikansi sebesar 0,020 <0,05 Maka keempat variabel bebas signifikan terhadap financial management behavior.

\section{Uji Determinasi}

Tabel 2 nilai Adjusted $R$ Square sebesar 0,434 menunjukkan bahwa proporsi pengaruh variabel bebas terhadap variabel terikat sebesar $43,4 \%$, sedangkan sisanya $56,6 \%$.dijelaskan variabel lain di luar penelitian ini.

Tabel 2

HASIL UJI DETERMINASI

\begin{tabular}{rrrrr}
\hline Model & \multicolumn{1}{c}{$\boldsymbol{R}$} & $\boldsymbol{R}$ Square & Adjusted $\boldsymbol{R}$ Square & Std. Error of the Estimate \\
\hline 1 & $.676^{\mathrm{a}}$ & .456 & .434 & 2.353 \\
\hline
\end{tabular}

Sumber: Output SPSS (data diolah)

\section{Pengaruh Financial Literacy terhadap Financial Management Behavior}

Financial literacy berpengaruh signifikan terhadap financial management behavior, sehingga hipotesis pertama (H1) diterima. Hasil tersebut disebabkan oleh seseorang dengan financial literacy yang baik akan memiliki kepiawaian untuk berpikir dan mengatasi tantangan dalam hidup, sehingga akan cenderung memiliki strategi yang lebih tepat dalam memenuhi kebutuhannya, dalam hal ini mahasiswa Universitas Negeri Surabaya dengan tingkat financial literacy baik maka akan berdampak pada tingkat financial magement behavior yang baik juga sebagai strategi yang digunakan untuk memenuhi kebutuhan hidupnya, yaitu untuk finansial jangka pendek ataupun jangka panjang. Hal ini terlihat dari kepiawaian mereka dalam pengelolaan keuangan pribadi, pengelolaan investasi dengan baik. Financial literacy berpengaruh signifikan positif terhadap pengelolaan finansial selaras dengan riset Herawati et al. (2018).

Implikasi dalam penelitian ini yaitu, hasil penelitian sesuai dengan Theory of Planned Behavior, financial literacy yang semakin baik akan berdampak pada semakin baik pula pemahaman finansial 
seseorang yang nantinya akan memengaruhi perilaku keuangannya. Dengan demikian mahasiswa mendapat lebih banyak wawasan terkait konsep finansial, mahasiswa akan mampu membuat keputusan yang lebih baik.

\section{Pengaruh Locus of Control terhadap Financial Management Behavior}

Locus of control terbukti signifikan memengaruhi financial management behavior, artinya hipotesis kedua (H2) diterima. Seseorang dengan tingkat kontrol diri yang bagus maka tingkat pengelolaan keuangannya juga akan semakin meningkat. Hasil tersebut selaras dengan teori yang memaparkan seseorang melihat apa yang terjadi dalam kehidupannya bergantung pada perilakunya sendiri dan masalah tersebut selalu bisa terpecahkan, serta lebih percaya kondisi keuangnya saat ini disebabkan oleh keterampilan dan usaha yang sudah dilakukannya. Hasil selaras dengan penelitian Rizkiawati \& Asandimitra (2018).

Implikasi dalam penelitian ini yaitu hasil penelitian sesuai dengan Social Learning Theory, di mana seseorang bertindak berdasarkan dengan lingkungan yang dianggapnya penting, kepribadian seseorang sifatnya terus dipelajari, kepribadian seseorang memiliki satu kesatuan mendasar, seseorang melakukan sesuatu berdasarkan apa yang ingin dicapai, dan seseorang mampu menangani masalah yang muncul. Selain itu, lingkungan sekitar juga sangat berpotensi dalam memengaruhi emosi atau cara pengendalian diri seseorang terkait penyusunan financial management behavior. Mahasiswa dengan pengendalian diri yang baik maka proses mereka memutuskan sesuatu berkaitan dengan masalah finansialnya juga semakin baik. Mereka mampu memahami diri mereka sendiri sehingga mampu menemukan cara memecahkan masalah yang dihadapinya.

\section{Pengaruh Life Style terhadap Financial Management Behavior}

Life style terbukti berpengaruh signifikan terhadap financial management behavior, artinya hipotesis ketiga (H3) diterima. Life style dapat dilihat dari kegiatan, keinginan serta pendapat yang dilakukan mahasiswa. Seseorang akan cenderung bersikap konsumtif tanpa adanya pemikiran rasional guna terpenuhi life style yang diingkan, sehingga berdampak terjadinya tindakan pengeluaran uang yang tidak terkontrol apabila tidak diimbangi dengan pengelolaan keuangan. Life style berpengaruh signifikan positif terhadap perilaku keuangan seseorang (Dewi \& Haryana, 2020).

Implikasi pada penelitian ini yaitu hasil sesuai dengan VALS yang mendasari bahwa cara seseorang dalam menentukan kebutuhan hidup dari dengan teori herarki kebutuhan hidup. Semakin tinggi pemahaman terhadap nilai guna suatu hal maka kemampuan seseorang dalam memetakan gaya hidup yang sesuai dengan kebutuhannya akan semakin teratur dan akibatnya financial management behavior yang dimiliki dapat berjalan.

Seperti halnya literasi keuangan yang akan sangat berdampak pada keputusan seseorang dalam financial management behavior yang dimilikinya. Pemahaman mahasiswa yang baik terkait nilai menjadi hal dasar yang mengarahkan hidup seseorang dan apa yang dipandang dalam kehidupan menjadi esensi penting tidaknya sebuah nilai, sehingga mahasiswa lebih selektif dalam menentukan gaya hidupnya yang nantinya akan berdampak pada perilaku keuangan mereka.

\section{Pengaruh Gender terhadap Financial Managemnet Behavior}

Gender terbukti memengaruhi financial management behavior secara signifikan, sehingga hipotesis keempat (H4) diterima. Hasil tersebut sejalan dengan penelitian Yunita (2020) bahwa gender memengaruhi perilaku keuangan seseorang. Namun hasil penelitian ini gender wanitalah yang memiliki nilai paling tinggi sehingga bertolak belakang dengan hasil observasi Yunita (2020) yang menyatakan laki-laki melakukan perencanaan keuangan lebih daik daripada wanita karena laki-laki memiliki pola pikir yang lebih logis dan mempunyai rasa tanggung jawab untuk memenuhi kebutuhan biaya hidup keluarganya.

Implikasi pada penelitian ini yaitu hasil sesuai dengan Theory of Planned Behavior, gender akan berpengaruh kepada cara pikir dan keputusan dalam perencanaan keuangan, karena pria dan wanita 
Novita Sari. Pengaruh Financial Literacy, Locus of Control, Life Style, dan Gender terhadap Financial Management Behavior Mahasiswa Universitas Negeri Surabaya

mempuanyai perbedaan beban yang ditanggung. Hal tersebut sejalan dengan asumsi mengenai individu bertindak atas dasar keinginanya sendiri, berdasarkan pada perkiraan logis mengenai dampak paling mungkin muncul dari sikap yang mereka lakukan. Mahasiswa baik laki-laki maupun perempuan mempunyai beban masing-masing yang harus ditanggung dan dengan pemahaman pentingnya pengelolaan keuangan yang baik sehingga kehidupan keuangan mereka akan lebih teratur.

\section{KESIMPULAN}

Variabel financial literacy, locus of control, life style, dan gender memengaruhi financial management behavior. Dari hasil penelitian diharapkan dapat digunakan sebagai bahan referensi perilaku keuangan seseorang secara mendetail mengenai financial literacy, locus of control, life style, dan gender dan diharapkan mahasiswa mampu menerapkan pengelolaan keuangan dengan baik, di mana mahasiswa mampu melakukan kontrol keuangan dengan baik sehingga pengalokasian keuangan mereka terarah.

Penelitian ini memiliki keterbatasan pada sampel yang sedikit, hanya menggunakan empat variabel bebas yaitu financial literacy, locus of control, life style, dan gender. Diharapkan hasil penelitian ini dapat berguna sebagai bahan tinjauan bagi pihak Universitas Negeri Surabaya dan OJK untuk memberikan edukasi-edukasi mengenai pentingnya mengelola dan merencanakan keuangan dengan baik di kalangan anak muda khususnya mahasiswa. Disarankan untuk penelitian berikutnya menambahkan variabel usia, kepribadian, dan pekerjaan orang tua.

\section{DAFTAR PUSTAKA}

Ajzen, I. (1991). The Theory of Planned Behavior. Organizational Behavior and Human Decision Processes, 50(2), 179-211.

Ajzen, I. (2005). Attitudes, Personality \& Behavior. In Open University Press (second, p. 191). Open University Press.

Azizah, N. S. (2020). Pengaruh literasi keuangan, gaya hidup pada perilaku keuangan pada generasi milenial. Prisma (Platform Riset Mahasiswa Akuntansi), 1(2), 92-101.

Baron, R. A., \& Byrne, D. (2000). Social Psychology, Massachusetts. Allyn and Bacon. Journal of Personality and Social Pychology, 53, 542-549.

BPS. (2018). Ragam Konsumsi Makanan Penduduk Jawa Timur 2017. (https://jatim.bps.go.id/publication/2018/12/26/ac5f52c055b6d11b3b40707/ragam-konsumsipenduduk-jawa-timur-2017.html. diakses pada 22 Oktober 2020)

Dew, J., \& Xiao, J. J. (2011). The Financial Management Behavior Scale: Development and Validation. Journal of Financial Counseling and Planning, 22(1), 43-59.

Dewi, R., \& Haryana, T. (2020). Pengaruh Life Style, self Control dan Financial Literacy terhadap Perilaku Konsumtif Mahasiwa Melakukan Online Shopping. Jurnal Ekonomi-ManajemenAkuntansi, 16(1), 29-36.

Dikria, O., \& Mintarti, S. U. (2016). Pengaruh literasi keuangan dan pengendalian diri terhadap perilaku konsumtif mahasiswa jurusan ekonomi pembangunan fakultas ekonomi universitas negeri malang angkatan 2013. Jurnal Pendidikan Ekonomi, 9(2), 128-139.

Halimatussakdiyah, Martono, S., \& Sudarma, K. (2019). Influence of Life Style and Financial Literacy to Consumptive Behavior through Self-Control of Unisnu FEB College Students Jepara. Journal of Economic Education, 8(37), 75-80. 
Herawati, N. T., Candiasa, I. M., Yadnyana, I. K., \& Suharsono, N. (2018). Factors That Influence Financial Behavior Among Accounting Students in Bali. International Journal of Business Administration, 9(3), 30-38. https://doi.org/10.5430/ijba.v9n3p30

Ida, \& Dwinta, C. Y. (2010). Pengaruh Locus of Control, Financial Knowledge , Income terhadap Financial Management Behavior. Jurnal Bisnis dan Akuntansi, 12(3), 131-144.

Indepth.com. (2020). Populasi Mileniel Potensial Menjadi Generasi Melek Keuangan. (https://www.indotelko.com/read/1580334079/populasi-keuangan. diakses pada 12 Oktober 2020)

Kencana, M. R. B. (2020). OJK Ungkap Penyebab Tingkat Literasi Keunagan Indonesia Rendah. Merdeka.Com. (https://m.merdeka.com/uang/ojk-ungkap-penyebab-tingkat-literasi-keuanganindonesia -rendah.html?page $=2$. diakses pada 11 Oktober 2020)

Kholilah, N. Al, \& Iramani, R. (2013). Studi Financial Management Behavior Pada Masyarakat Surabaya. Journal of Business and Banking, 3(1), 69-80.

Kostakis, I. (2012). The Determinationts of Households' Food Consumption in Greece. International Journal of Food and Agricultural Economics, 2(2), 17-28.

Kunto, Y. S., \& Pasla, P. R. (2006). Segmentasi Gaya Hidup pada Mahasiswa Program Studi Pemasaran Universitas Kristen Petra. Jurnal Manajemen Pemasaran, 1(1), 13-21.

Margaretha, F., \& Pambudhi, R. A. (2015). Tingkat Literasi Keuangan Mahasiswa S-1 Fakultas Ekonomi. Jurnal Manajemn Dan Kewirausahaan, 17(1), 76-85. https://doi.org/10.9744/jmk.17.1.76

Mien, N. T. N., \& Thao, T. P. (2015). Factors Affecting Personal Financial Management Behaviors : Evidence from Vietnam. Proceedings of the Second Asia-Pacific Conference on Global Business, Economics, Finance and Social Sciences (AP15Vietnam Conference).

Nidar, S. R., \& Bestari, S. (2021). Personal Financial literacy Among University Students (case Study at Padjadjaran University Students, Bandung, Indonesia). World Journal of Sosial Sciences, 2(4), 162-171.

Ningtyas, M. N. (2019). Literasi keuangan Pada Generasi Milenial. Jurnal Ilmiah Bisnis Dan Ekonomi Asia, 13(1), 20-27. https://doi.org/10.32812/jibeka.v13i1.111

Otoritas Jasa Keuangan. (2019). Survei OJK 019: Indeks Literasi dan Inklusi Keungan Meningkat. (https://www.ojk.go.id/berita-dan-kegiatan/publikasi/Pages/Survei-Nasional-Literasi-danInklusi-Keuangan-2019.diakses pada 11 Oktober 2020)

PDDIKTI. (2020). Profil Universitas Negeri Surabaya. (https://pddikti.kemendikbud.go.id/datapt/N0M5MzM4RkQtQ0QyRi00QjgwLUiyRUUtMjQxMDYxNUExMzJB. diakses pada 23 Oktober 2020)

Purwidianti, W. (2018). An Empirical Study on Family Financial Behavior. International Conference on Community Development, 231(1), 406-409.

Putri, N. A., \& Lestari, D. (2019). Pengaruh Gaya Hidup dan Literasi Keuangan Muda di Jakarta. Jurnal Riset Akuntansi dan Keuangan, 1(1), 31-42.

Rizkiawati, N. L., \& Asandimitra, N. (2018). Pengaruh Demografi, Financial Knowledge, Financial Attitude, Locus of Control Dan Financial Self-Efficacy Terhadap Financial Management 
Novita Sari. Pengaruh Financial Literacy, Locus of Control, Life Style, dan Gender terhadap Financial Management Behavior Mahasiswa Universitas Negeri Surabaya

Behavior Masyarakat Surabaya. Jurnal Ilmu Manajemen (JIM), 6(3), 93-107.

Robb, C. A., \& Woodyard, A. S. (2011). Financial Knowledge and Best Practice Behavior. Journal of Financial Counseling and Planning, 22(1), 60-70.

Rotter, J. B. (1966). Generalized Expectancies For Internal Versus External Control of Reinforcement. Psychological Monographs: General and Applied, 80(1), 1-28. https://doi.org/10.1037/h0092976

Setiadi, N. J. (2003). Perilaku Konsumen Perspektif Kontemporer pad Motif, Tujuan, dan Keinginan Konsumen. Prenada Media Group.

Siregar, B. P. (2020). Masih Banyak Kalangan Milenial Belum Melek Keuangan. Warta Ekonomi.Co.Id. (https://www.wartaekonomi.co.id/read316783. diakses 13 januari 2021)

Sriwijaya, M. (2017). Pengaruh Locus of Control dan financial knowledge terhadap Financial Behavior Mahasiswa Penerima Bidikmisi Uin Alaudin Makassar. Jurnal Ekonomi,Manajemen, Dan Akuntansi, 1(1), 64-72.

Sujarweni, V. W. (2015). Metodologi Penelitian Bisnis dan Ekonomi (Cetakan Pertama). Bandung. Pustaka Baru Perss.

Suryanto. (2017). Pola Perilaku Keuangan Mahasiswa di Perguruan Tinggi. Jurnal Ilmu Politik Dan Komunikasi (JIPSI), 7(1), 11-20.

Widyawati, I. (2012). Faktor- Faktor yang Mempengaruhi Literasi Finansial Mahasiswa Fakultas Ekonomi dan Bisnis Universitas Brawijaya. Jurnal Akuntasin Dan Pendidikan, 1(1), 89-99. https://doi.org/http://doi.org/10.25273/jap.v1i1.527

Yunita, N. (2020). Pengaruh Gender dan Kemampuan Akademis terhadap Literasi Keuangan dalam Perilaku Pengelolaan Keuangan pada Mahasiswa Jurusan Akuntansi. Prisma (Platform Riset Mahasiswa Akuntansi), 01(2013), 1-12.

Yushita, A. N. (2017). Pentingnya Literasi Keuangan Bagi Pengelolaan Keuangan Pribadi. Jurnal Nominal, VI(9), 1689-1699. 